\title{
Prostatic Stroma
}

National Cancer Institute

\section{Source}

National Cancer Institute. Prostatic Stroma. NCI Thesaurus. Code C13104.

The non-glandular tissue of the prostate gland, consisting of two major cell types,

smooth muscle cells and fibroblasts. Stromal cells are key regulators of growth and differentiation in the prostate. 